\title{
Insulin Responsiveness of Superficial Forearm Tissues in Type 2 (Non-Insulin Dependent) Diabetes
}

\author{
N. Kalant, D. Leibovici, N. Fukushima, J. Kuyumjian and S. Ozaki \\ Lady Davis Institute for Medical Research, Sir Mortimer B. Davis Jewish General Hospital, Montreal, Quebec, Canada
}

Summary. Forearm perfusion studies were carried out to determine the responsiveness to insulin of the superficial forearm tissues in non-obese Type 2 (noninsulin-dependent) diabetics, and the interrelationships among plasma concentrations of glucose, insulin and non-esterified fatty acids (NEFA), tissue uptake of glucose and insulin and tissue release of NEFA. It was found that: (1) in normal subjects, uptake of glucose was dependent on glucose concentration. It was also dependent on insulin concentration in the range of $0-30 \mathrm{mU} / 1$, but not over a wider range of insulin concentration $(<66 \mathrm{mU} / \mathrm{l})$, indicating that the insulin effect was maximal at approximately $30 \mathrm{mU} / 1$. In contrast, glucose uptake in diabetics was independent of glucose concentration but dependent on insulin uptake over an insulin concentration range up to $140 \mathrm{mU} / 1$; glucose uptake reached the same levels as in control subjects but only at higher concentration and higher uptake of insulin. (2) Insulin uptake was directly dependent on insulin concentration and the regression coefficients were very similar in the two groups. (3) NEFA concentration fell to comparable levels in the two groups of subjects in response to insulin. It is concluded that in Type 2 diabetes: (1) the superficial forearm tissues show decreased responsiveness to the stimulatory effect of both hyperglycaemia and hyperinsulinaemia on glucose utilization but the NEFA-lowering effect of insulin is undiminished, and (2) tissue uptake of insulin is normal, despite the decrease in receptor capacity that has been demonstrated by others.

Key words: Forearm, superficial tissues, glucose uptake, insulin uptake, NEFA release, glucose concentration, insulin concentration, NEFA concentration, diabetes.

Since it was first described by Himsworth [1], decreased responsiveness to insulin has been demonstrated in Type 2 (non-insulin-dependent) diabetes by a variety of techniques [2-5]. This unresponsiveness is independent of obesity which is also associated with a decreased hypoglycaemic response to insulin [6]. Using a variety of isotope procedures to measure glucose production and utilization, several authors have demonstrated that in normal subjects stimulation of glucose uptake is a less sensitive response to insulin than is suppression of hepatic glucose production [7], but that in diabetes it is impaired earlier and more severely than inhibition of hepatic glucose production [8-10]. In an attempt to determine which tissues are involved in the diminished insulin stimulation of glucose uptake, we previously studied the response of forearm muscle to insulin and found that in nonobese Type 2 diabetics the sensitivity of this tissue was normal despite the presence of decreased total body responsiveness to insulin [11]. We now report on the response to insulin of the superficial forearm tissues.

\section{Subjects and Methods}

Forearm perfusion studies were carried out on 12 control subjects (four females, eight males; aged $44 \pm 2$ years) and ten diabetic patients (two females, eight males; aged $48 \pm 3$ years). A detailed explanation of the experiments was given and consent obtained. All subjects were within $8 \%$ of ideal body weight. The non-diabetics were healthy volunteers, who had no family history of diabetes or other metabolic disease and took no medications. Preparation of subjects was as previously described [11]; a diet containing 250-300 g carbohydrate was taken for 3 days preceding the experimental procedure and no food was taken for 14-15 h immediately before the study. The diabetic subjects were all Type 2 ; they were in good health apart from the diabetes and were leading normal active lives. The clinical features of the patients studied are shown in Table 1 . All took a diet containing at least $225 \mathrm{~g}$ of carbohydrate daily; all but one took an oral hypoglycaemic agent. None had previously received insulin. The last dose of hypoglycaemic drug was taken $48 \mathrm{~h}$ before the procedure. The technique of forearm perfusion, including the use of arterialized venous blood in place of arterial blood, was similar to that used for investigation of forearm muscle [11, 12]: venous blood was sampled from the cephalic vein of the forearm and a strain gauge for forearm blood flow measurement was placed around the same forearm; on the contralateral side an infusion of glucose and insulin (pork, monocomponent) was given into an antecubital vein and blood was sampled from a 
Table 1. Clinical features of diabetic subjects

\begin{tabular}{|c|c|c|c|c|}
\hline $\begin{array}{l}\text { Experi- } \\
\text { ment }\end{array}$ & Sex & $\begin{array}{l}\text { Duration of } \\
\text { diabetes } \\
\text { (years) }\end{array}$ & $\begin{array}{l}\text { Hypoglycaemic } \\
\text { agent } \\
\text { (daily dose) }\end{array}$ & $\begin{array}{l}\text { Other } \\
\text { medication } \\
\text { (daily dose) }\end{array}$ \\
\hline 1 & M & 10 & $\begin{array}{l}\text { Chlorpropamide } \\
\text { (250 mg) }\end{array}$ & \\
\hline 2 & $M$ & 19 & $\begin{array}{l}\text { Chlorpropamide } \\
(500 \mathrm{mg})\end{array}$ & \\
\hline 3 & M & 7 & $\begin{array}{l}\text { Glibenclamide } \\
(5 \mathrm{mg})\end{array}$ & $\begin{array}{l}\text { Diphenyl- } \\
\text { hydantoin } \\
\text { (200 mg) }\end{array}$ \\
\hline 4 & M & $1 / 4$ & $\begin{array}{l}\text { Chlorpropamide } \\
(250 \mathrm{mg})\end{array}$ & \\
\hline 5 & M & 3 & $\begin{array}{l}\text { Chlorpropamide } \\
(500 \mathrm{mg})\end{array}$ & \\
\hline 6 & M & 6 & Metformin (1 g) & \\
\hline 7 & M & 5 & $\begin{array}{l}\text { Chlorpropamide } \\
(500 \mathrm{mg})\end{array}$ & \\
\hline 8 & $\mathrm{~F}$ & 7 & $\begin{array}{l}\text { Chlorpropamide } \\
(500 \mathrm{mg}) \\
\text { Metformin }(1 \mathrm{~g})\end{array}$ & $\begin{array}{l}\text { Thyroxin }^{\mathrm{a}} \\
(0.15 \mathrm{mg})\end{array}$ \\
\hline 9 & $\mathrm{~F}$ & 4 & - & \\
\hline 10 & M & 7 & $\begin{array}{l}\text { Chlorpropamide } \\
(500 \mathrm{mg}) \\
\text { Metformin } \\
(0.5 \mathrm{~g})\end{array}$ & \\
\hline
\end{tabular}

For non-toxic nodular goitre

Table 2. Multiple regression analysis of total glucose utilization $\left(\mathrm{mg} \cdot \mathrm{min}^{-1} \cdot \mathrm{kg}^{-1}\right)$

\begin{tabular}{llll}
\hline & Independent variable & $\begin{array}{l}\text { Regression } \\
\text { coefficient }\end{array}$ & $p$ \\
\hline $\begin{array}{l}\text { Control } \\
\text { subjects }\end{array}$ & $\begin{array}{l}\text { Glucose concentration } \\
\text { (mmol/1) } \\
\text { Insulin concentration } \\
\text { (mU/1) }\end{array}$ & -0.29 & $\mathrm{NS}$ \\
$\begin{array}{l}\text { Diabetic } \\
\text { subjects }\end{array}$ & $\begin{array}{l}\text { Glucose concentration } \\
\text { (mmol/1) } \\
\text { Insulin concentration } \\
\text { (mU/1) }\end{array}$ & -0.68 & 0.005 \\
\hline $\mathrm{NS}=$ not significant & 0.70 & 0.01 \\
\hline
\end{tabular}

vein on the dorsum of the hand which was warmed to increase blood flow so that the venous blood was 'arterialized'. Blood flow was measured by strain gauge plethysmography [14]; no occlusive cuff was used at the wrist, so that the blood flow measurements were for the forearm and hand [19].

The experimental protocol was similar to that used previously. In principle, subjects were studied in the basal state and during one or two periods of steady-state hyperglycaemia produced by a glucose injection and infusion and maintained by a 'glucose-clamp' technique [11]; however basal data were not obtained in one subject of each group. Five control subjects and eight diabetics also received a separate insulin infusion at a constant rate of 25 or $50 \mathrm{mU} /$ min during the periods of glucose infusion to provide a greater range of plasma insulin concentrations than obtained with glucose infusion alone.

In several preliminary experiments Evans Blue was injected slowly in a retrograde direction through a catheter placed in a deep vein of the forearm and samples were taken simultaneously from the superficial vein; no dye was detected in the superficial vein samples unless an occlusive cuff was placed around the upper arm.
It was concluded that at rest communication between the deep vein and the cephalic vein was not significant and that samples from the cephalic vein were reasonably representative of superficial tissue drainage.

Following positioning of the indwelling needles or a change in the infusion rate of glucose or insulin to achieve a new level of glycaemia, there was an adjustment period to permit stabilization of the glucose concentration. When this had been steady for $1 \mathrm{~h}$, blood flow was measured and arterialized and superficial vein blood were sampled three to four times at 15 -min intervals. Blood flow was measured 12-15 times over a 5-min period; immediately afterwards blood was drawn simultaneously from the superficial vein and from the arterialized vein, placed in heparinized tubes and stored on ice for subsequent separation of plasma and measurement of glucose, insulin and NEFA. From the arteriovenous concentration differences and the blood flow, calculations were made of glucose uptake, insulin uptake and NEFA release by the superficial forearm tissues. The mean concentration and uptake values for each steady-state period were used for subsequent statistical analyses.

Plasma glucose was measured with an oxygen electrode glucose analyzer (Beckman Instruments) and NEFA was measured by the method of Trout et al. [15]. Plasma insulin was measured by a radioreceptor assay [16] having a sensitivity of $0.48 \mathrm{mU} / 1$ for standard insulin and $0.71 \mathrm{mU} / 1$ for plasma insulin and an interassay coefficient of variation of $5.5 \%$. The haematocrit was measured on all samples to verify that there had been no dilution by the saline used to wash out the IV catheters.

Kontos et al. [17] demonstrated that blood flow to the skin was a fairly constant fraction of total forearm blood flow in the resting $\operatorname{limb}\left(40 \pm 4 \%\right.$ over the range of 1 to $4 \mathrm{ml} \mathrm{min}^{-1} 100 \mathrm{ml}$ tissue $\left.{ }^{-1}\right)$; Zelis et al. [18] obtained an average value of $48 \%$ under similar circumstances. We have therefore assumed that the fraction of flow going to the superficial tissues was the same in all subjects. The ratio of superficial to deep tissues (muscle and bone) is greater in the hand than in the forearm so that the superficial flow in the hand-forearm was an even greater fraction of the total than in forearm alone. To validate this approach measurements were made which demonstrated that the amounts of superficial tissue were comparable in the two groups: (a) The ratio of hand volume to forearm volume, measured by water displacement, was identical for the normal and diabetic subjects $(0.33 \pm 0.01$ and $0.35 \pm 0.01$, respectively); (b) The amount of adipose tissue in the forearm was determined from a computerized tomography scan taken at a level one-third of the distance from the antecubital skin crease to the wrist crease; the area of adipose tissue on the scan was taken as the difference between the total cross-sectional area and that of the muscle-bone, measured by planimetry. The ratio (adipose tissue area :total forearm area) was found to correlate well with the ratio (body weight :ideal body weight $)(r=0.84, p<0.01)$. The equation for regression of the area ratio on the weight ratio for non-diabetics was $y=$ $-0.63+0.82 x$ and that for diabetics was $y=-0.76+0.93 x$; the differences between the slopes and elevations of the regression lines were not significant $(p>0.25)$. Thus the values for total flow, while not correct estimates of superficial flow in absolute terms, are valid, within the variations noted, for comparative purposes.

Calculations of tissue uptake of glucose and insulin and of release of NEFA were made from the arteriovenous concentration differences and the plasma flow (blood flow corrected for haematrocrit) according to the Fick principle. The mean concentration and uptake values for each steady-state period were analyzed by multiple regression analyses with step-wise addition of the independent variables in decreasing order of their contribution to the sum of squares for regression [19]. This analysis also provides the standardized regression coefficient $(\beta)$, i. e. the regression coefficient which would obtain if units of measurement were adjusted so that the standard deviation of each parameter $=1$, thus allowing direct comparison of regression coefficients based on different parameters. 


\section{Results}

\section{Total Body Glucose Utilization}

It was assumed that the total rate of glucose utilization during steady-state hyperglycaemia produced by glucose infusion was equal to the mean infusion rate during that period. Simple regression analysis showed a close relationship between total glucose utilization and insulin concentration in both diabetics (regression equation: $y=1.18+0.17 x$ ) and non-diabetics (regression equation: $y=2.47+0.04 x$ ); the difference in slopes was significant at $p<0.001$. This was confirmed by the multiple regression analysis which demonstrated that for both groups glucose utilization was strongly dependent on insulin concentration but independent of glucose concentration (Table 2). The regression coefficient for utilization on insulin concentration in the diabetics was reduced to about $25 \%$ of that of the non-diabetics ( $p<0.001$ for difference between regression coefficients) thus demonstrating the insulin unresponsiveness of these patients.

\section{Tissue Uptake of Glucose and Insulin and Release of NEFA}

The results of individual experiments are shown in Table 3. Mean plasma flow measurements for hand and forearm were $3.4 \pm 0.2$ for non-diabetics and 3.8 $\pm 0.2 \mathrm{ml} \mathrm{min}^{-1} 100 \mathrm{ml}$ tissue $\mathrm{e}^{-1}$ for diabetic patients. Multiple regression analyses were carried out in turn with glucose uptake, insulin uptake, NEFA concentration (arterial) and NEFA release as the dependent variable and all other parameters as independent variables. The significant regressions are shown in Table 4. Glucose uptake in controls was dependent on glucose concentration while in diabetics it was related to insulin uptake. While in the control group as a whole glucose uptake was independent of insulin concentration, in those in whom the insulin concentration was $<30 \mathrm{mU} / 1$ glucose uptake was dependent on insulin concentration ( $\mathrm{B}=0.41, \beta=0.44, p<0.02$ ). In control subjects NEFA concentration was strongly related to insulin concentration, while in the diabetics it was dependent on insulin uptake; the standardized regression coefficients indicate that the responsiveness of the diabetics to insulin uptake was greater than that of the control subjects to insulin concentration. In both groups insulin uptake was determined by insulin concentration and the regression coefficients were very close (Table 4). In addition, in nondiabetics glucose concentration stimulated insulin uptake to a significant degree. In neither group was there clear evidence of control of NEFA release by the variables considered in this study, the $p$ values falling just beyond the usually accepted level of significance of 0.05 .

\section{Discussion}

These results confirm [11] that the rate of total body glucose utilization by both diabetics and non-diabetics is controlled by the plasma insulin concentration but not by the plasma glucose concentration, when this is above the normal basal level and that nonobese Type 2 diabetic patients are relatively unresponsive to insulin $[2-5,11]$.

The relationships anticipated in the superficial tissues of the control subjects are described in Figure 1A. The apparent failure of insulin to influence the glucose uptake in normal subjects (Fig. 1B) agrees with earlier observations [20] and appears to conflict with the ability of insulin to increase glucose uptake by adipocytes in vitro. However this effect in vitro is maximal at concentrations of 15-25 mU/1 [21-24]; in the present work also, when the insulin concentration was $<30 \mathrm{mU} / 1$, glucose uptake was dependent on insulin concentration, but when all data were pooled this relationship was masked by the absence of a relationship at higher concentrations. Contrary to the results in skeletal muscle [11] glucose uptake was dependent on glucose concentration. Since adipose tissue accounts for only a small percentage of total glucose utilization $[25,26]$, this effect of glucose concentration on the superficial forearm tissues is not evident in the results for total body glucose utilization.

In the diabetic subjects (Fig. 1C) insulin uptake was the only determinant of glucose uptake. The mean glucose uptake was not significantly different from that of the controls but it occurred at higher mean levels of insulin concentration and insulin uptake (Table 2). These results suggest that there is a defect in glucose metabolism manifested by a failure to respond directly to glucose concentration, as well as a defect in the response to insulin, manifested by a weak stimulation of glucose uptake which persists even at concentrations which elicit a maximal response in normal tissue (i. e. a 'shift to the right' of the insulin dose-response curve).

The strong relationship between insulin uptake and insulin concentration is similar to that seen in muscle [11]. However studies on the effect of glucose concentration on insulin removal have been inconsistent [27-29]. Our finding of the dependence of insulin uptake on glucose concentration in non-diabetic subjects agrees with that of Tiran et al. [29]; the lack of a glucose effect in diabetics is further evidence of a failure to respond to the glucose concentration.

The physiological substrate for insulin degradation is receptor-bound insulin [30,31]. The number of insulin receptors is reduced in Type 2 diabetics [32-35] and in comparable animal models [36-38]; though most of our diabetic subjects received sulphonylureas, which can partially overcome this reduction, it is likely that the receptor number was still 
Table 3. Experimental data from forearm perfusion studies

\begin{tabular}{|c|c|c|c|c|c|c|c|c|}
\hline Experiment & $\begin{array}{l}\text { Glucose } \\
\text { infusion } \\
\left(\mathrm{mg} \cdot \mathrm{min}^{-1}\right. \\
\left.\cdot \mathrm{kg}^{-1}\right)\end{array}$ & $\begin{array}{l}\text { Insulin } \\
\text { infusion } \\
(\mathrm{mU} / \mathrm{min})\end{array}$ & $\begin{array}{l}\text { Arterial } \\
\text { glucose } \\
(\mathrm{mmol} / 1)\end{array}$ & $\begin{array}{l}\text { Glucose uptake } \\
\text { mg } \cdot \mathrm{min}^{-1} \\
\cdot 100 \mathrm{ml} \\
\text { tissue }^{-1} \text { ) }\end{array}$ & $\begin{array}{l}\text { Arterial } \\
\text { insulin } \\
(\mathrm{mU} / 1)\end{array}$ & $\begin{array}{l}\text { Insulin uptake } \\
\left(\mu \mathrm{U} \cdot \mathrm{min}^{-1}\right. \\
\cdot 100 \mathrm{ml} \\
\left.\text { tissue }-^{-5}\right)\end{array}$ & $\begin{array}{l}\text { Arterial } \\
\text { NEFA } \\
(\mathrm{mmol} / \mathrm{l})\end{array}$ & $\begin{array}{l}\text { NEFA release } \\
\left(\mathrm{mmol} \cdot \mathrm{min}^{-1}\right. \\
\cdot 100 \mathrm{ml} \\
\text { tissue }^{-1}\end{array}$ \\
\hline \multicolumn{9}{|c|}{ Non-diabetic subjects } \\
\hline \multirow[t]{2}{*}{1} & - & - & 5.0 & 0.02 & 2 & 2 & 1.09 & -0.26 \\
\hline & 4.45 & - & 8.9 & 0.11 & 30 & 22 & 0.68 & -0.43 \\
\hline \multirow[t]{2}{*}{2} & - & - & 4.7 & 0.07 & 4 & 0 & 0.36 & 0.22 \\
\hline & 4.66 & - & 7.8 & 0.17 & 18 & 10 & 0.15 & 0.45 \\
\hline \multirow[t]{2}{*}{3} & - & - & $5.0^{\circ}$ & 0.14 & 10 & 9 & 0.83 & -0.24 \\
\hline & 3.63 & - & 8.6 & 0.26 & 26 & 16 & 0.35 & 0.12 \\
\hline \multirow[t]{2}{*}{4} & - & - & 4.7 & 0.04 & 4 & 1 & 0.54 & 0.27 \\
\hline & 5.95 & - & 8.3 & 0.16 & 21 & 16 & 0.20 & -0.03 \\
\hline \multirow[t]{2}{*}{5} & - & - & 5.3 & 0.11 & 5 & 2 & 0.56 & -0.00 \\
\hline & 3.30 & - & 9.3 & 0.21 & 17 & 8 & 0.32 & 0.01 \\
\hline \multirow[t]{3}{*}{6} & - & - & 4.6 & 0.08 & 2 & -2 & 1.05 & 0.58 \\
\hline & 3.61 & - & 8.3 & 0.09 & 18 & 14 & 0.67 & 0.03 \\
\hline & 6.71 & - & 10.4 & 0.01 & 28 & 25 & 0.51 & 0.08 \\
\hline \multirow[t]{3}{*}{7} & - & - & 4.7 & -0.05 & 8 & 5 & 0.53 & 0.03 \\
\hline & 6.72 & 0.25 & 7.1 & 0.10 & 39 & 27 & 0.23 & 0.01 \\
\hline & 9.70 & 0.50 & 6.7 & 0.09 & 53 & 25 & 0.20 & -0.01 \\
\hline \multirow[t]{3}{*}{8} & - & - & 4.8 & 0.07 & 1 & -3 & 0.62 & 0.33 \\
\hline & 2.14 & - & 6.8 & 0.09 & 9 & 2 & 0.48 & 0.09 \\
\hline & 3.81 & - & 9.2 & 0.13 & 18 & 33 & 0.27 & 0.14 \\
\hline \multirow[t]{3}{*}{9} & - & - & 5.1 & 0.09 & 1 & 1 & 0.67 & -0.21 \\
\hline & 3.75 & 0.25 & 7.8 & 0.08 & 13 & 14 & 0.17 & 0.11 \\
\hline & 13.22 & 0.50 & 5.6 & 0.05 & 66 & 35 & 0.20 & -0.20 \\
\hline 10 & 14.40 & 0.50 & 6.2 & 0.16 & 44 & 24 & 0.20 & 0.09 \\
\hline \multirow[t]{2}{*}{11} & 3.52 & - & 8.4 & 0.29 & 23 & 32 & 0.21 & 0.06 \\
\hline & 7.52 & 0.50 & 5.8 & 0.02 & 60 & 87 & 0.16 & 0.03 \\
\hline \multirow[t]{3}{*}{12} & - & - & 4.6 & 0.04 & 0 & 0 & 0.45 & -0.00 \\
\hline & 3.80 & - & 11.0 & 0.15 & 10 & 2 & 0.15 & 0.01 \\
\hline & 8.67 & 0.25 & 5.3 & 0.01 & 34 & 67 & 0.10 & -0.04 \\
\hline \multicolumn{2}{|c|}{ Mean \pm SEM } & & $6.8 \pm 0.3$ & $0.10 \pm 0.01$ & $20 \pm 3$ & $19 \pm 5$ & $0.43 \pm 0.05$ & $0.03 \pm 0.04$ \\
\hline \multicolumn{9}{|c|}{ Diabetic subjects } \\
\hline 1 & 1.55 & - & 11.0 & 0.09 & 4 & 2 & 0.50 & 0.83 \\
\hline \multirow[t]{2}{*}{2} & - & - & 9.1 & 0.02 & 13 & 6 & 1.18 & -0.07 \\
\hline & 3.73 & 0.50 & 11.6 & 0.13 & 84 & 51 & 0.79 & -0.06 \\
\hline \multirow[t]{3}{*}{3} & - & - & 6.7 & -0.05 & 2 & 5 & 0.60 & -0.24 \\
\hline & 3.47 & 0.25 & 8.9 & 0.10 & 33 & 60 & 0.32 & 0.17 \\
\hline & 7.82 & 0.50 & 10.5 & 0.27 & 43 & 56 & 0.27 & 0.04 \\
\hline 4 & - & - & 5.5 & 0.05 & 7 & -1 & 0.42 & -0.03 \\
\hline & 3.33 & - & 10.5 & 0.10 & 20 & 61 & 0.30 & 0.38 \\
\hline 5 & - & - & 10.9 & 0.13 & 6 & 8 & 0.81 & 0.74 \\
\hline & 3.28 & 0.25 & 15.3 & 0.27 & 21 & 4 & 0.50 & 0.44 \\
\hline & 4.53 & 0.50 & 15.1 & 0.12 & 55 & 41 & 0.42 & 0.21 \\
\hline 6 & - & - & 5.9 & 0.04 & 27 & 25 & 0.74 & 0.06 \\
\hline & 3.20 & 0.25 & 10.6 & 0.24 & 41 & 69 & 0.48 & 0.13 \\
\hline & 4.93 & 0.50 & 9.4 & 0.49 & 99 & 103 & 0.36 & 0.23 \\
\hline 7 & - & - & 5.0 & 0.03 & 9 & 6 & 0.50 & 0.17 \\
\hline & 6.59 & 0.50 & 8.4 & 0.21 & 56 & 105 & 0.09 & -0.23 \\
\hline 8 & - & - & 11.1 & -0.08 & 6 & 0 & 0.74 & 0.02 \\
\hline & 3.51 & 0.50 & 6.2 & 0.07 & 44 & 52 & 0.15 & 0.02 \\
\hline 9 & - & - & 7.6 & 0.06 & 3 & 0 & 0.72 & 0.06 \\
\hline & 6.58 & 0.25 & 8.9 & 0.18 & 81 & 105 & 0.19 & 0.05 \\
\hline & 9.05 & 0.50 & 7.6 & 0.17 & 142 & 139 & 0.26 & -0.04 \\
\hline 10 & - & - & 13.4 & 0.01 & 0 & 0 & 0.69 & 0.05 \\
\hline & - & 0.50 & 11.8 & 0.05 & 42 & 116 & 0.32 & -0.36 \\
\hline Mean $\pm \mathrm{SEI}$ & 4 & & $10.1 \pm 0.3$ & $0.12 \pm 0.03$ & $38 \pm 8$ & $41 \pm 9$ & $0.50 \pm 0.06$ & $0.13 \pm 0.06$ \\
\hline $\begin{array}{l}\text { Significance } \\
\text { from non-dia }\end{array}$ & $\begin{array}{l}\text { of difference } \\
\text { betic }(p)\end{array}$ & & 0.001 & - & 0.025 & 0.03 & 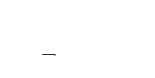 & - \\
\hline
\end{tabular}


Table 4. Multiple regression analysis of tissue uptake of glucose and insulin, tissue release of NEFA and arterial NEFA concentration

\begin{tabular}{|c|c|c|c|c|c|c|c|}
\hline & \multirow[t]{2}{*}{ Independent variable } & \multicolumn{3}{|l|}{ Non-diabetic } & \multicolumn{3}{|l|}{ Diabetic } \\
\hline & & $\begin{array}{l}\text { Partial } \\
\text { regression } \\
\text { coefficient }\end{array}$ & $\begin{array}{l}\text { Standardized } \\
\text { partial } \\
\text { regression } \\
\text { coefficient }\end{array}$ & $p$ & $\begin{array}{l}\text { Partial } \\
\text { regression } \\
\text { coefficient }\end{array}$ & $\begin{array}{l}\text { Standardized } \\
\text { partial } \\
\text { regression } \\
\text { coefficient }\end{array}$ & $p$ \\
\hline Glucose uptake & $\begin{array}{l}\text { Glucose concentration } \\
\text { Insulin uptake }\end{array}$ & 0.16 & 0.47 & 0.045 & $0.19 \times 10^{-2}$ & 0.56 & 0.01 \\
\hline Insulin uptake & $\begin{array}{l}\text { Insulin concentration } \\
\text { Glucose concentration }\end{array}$ & $\begin{array}{l}0.84 \\
4.21\end{array}$ & $\begin{array}{l}0.59 \\
0.35\end{array}$ & $\begin{array}{l}0.001 \\
0.03\end{array}$ & 0.78 & 0.68 & 0.001 \\
\hline NEFA concentration & $\begin{array}{l}\text { Insulin concentration } \\
\text { Insulin uptake }\end{array}$ & $-0.78 \times 10^{-2}$ & -0.55 & 0.002 & $-0.72 \times 10^{-2}$ & -1.18 & 0.01 \\
\hline NEFA release & $\begin{array}{l}\text { Insulin uptake } \\
\text { Insulin concentration }\end{array}$ & $-0.51 \times 10^{-2}$ & -0.43 & 0.066 & $-0.35 \times 10^{-2}$ & -0.49 & 0.061 \\
\hline
\end{tabular}

Units of measurement are the same as those shown in Table 3
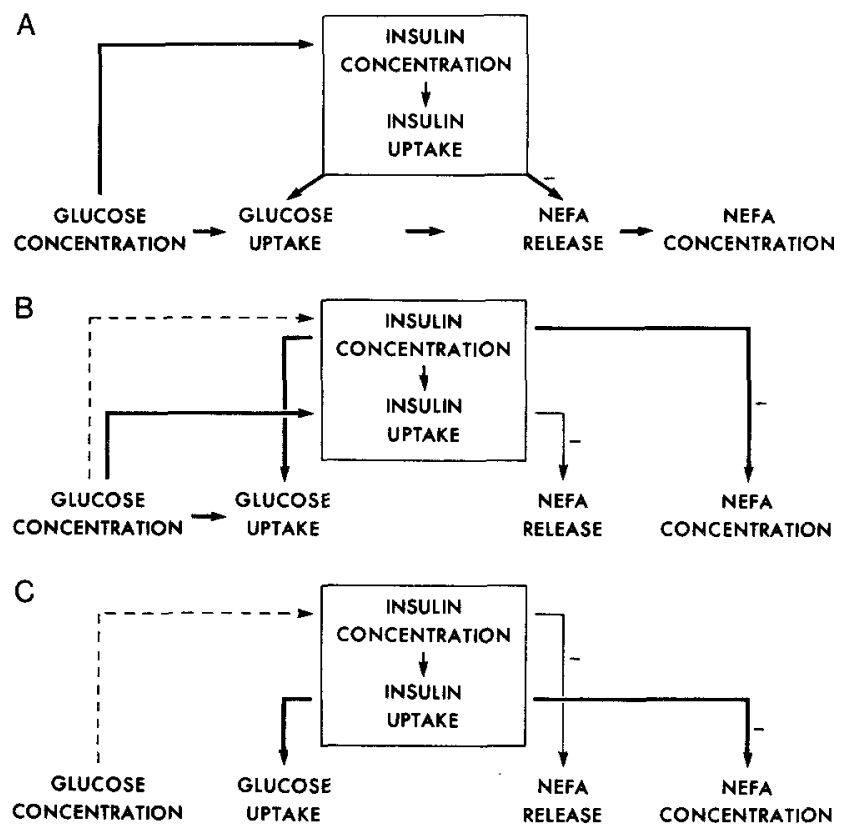

Fig. 1 A-C. A Hypothetical relationships between glucose, insulin and NEFA. Glucose concentration controls glucose uptake directly as well as indirectly through the action of insulin. NEFA release is controlled by the availability of intracellular glucose and by the direct antilipolytic action of insulin; NEFA release in turn determines NEFA concentration. The arrows indicating the insulin effects come from an insulin 'black box' since the mechanisms coupling insulin to its sites of metabolic action are unknown. B Relationships found in control subjects. The effect of insulin concentration on glucose uptake was found only at insulin concentrations $<30 \mathrm{mU} / 1$. C Relationships found in diabetic subjects. In $\mathbf{B}$ and $\mathbf{C}$ dashed arrows indicate an effect which could not be measured, but is assumed. The light arrows show relationships defined by a regression coefficient of $p$ approximately 0.06

reduced by $30-40 \%[39,40]$. Since the rate of uptake, which includes binding, internalization and degradation [41], was not reduced it is concluded that the receptor number was not rate-limiting for insulin metabolism.
Contrary to expectations (Fig. 1 A) in neither group of subjects was there a demonstrable correlation between NEFA release and NEFA concentration; furthermore the influence of insulin appeared to be directly on NEFA concentration and, in agreement with the finding of Zierler and Rabinowitz [20], the suppression of serum NEFA by insulin was not dependent on increased glucose uptake. Thus none of the variables had a clear effect on the rate of NEFA release; presumably other, unmeasured factors control this function.

While the NEFA concentration was affected by insulin in both groups, the response of the diabetics was greater than that of normal subjects; thus, in agreement with the results of Howard et al. [42], the diabetic subjects had decreased responsiveness to the stimulatory action of insulin on glucose uptake but not to its NEFA-lowering action. These results, together with those for forearm muscle [11], demonstrate that decreased responsiveness to insulin is specific for both tissue and metabolic pathway. They also indicate that the antilipolytic action of insulin, like insulin uptake, is not limited by a decrease in insulin receptors.

Acknowledgements. This work was supported by a grant from the Medical Research Council of Canada. We are indebted to Dr. J.-C. Lasry, Department of Psychiatry, Jewish General Hospital and Département de Psychologie, Université de Montréal, for the statistical analyses and consultations on the interpretation of the results.

\section{References}

1. Himsworth HP (1936) Diabetes mellitus. Lancet 1: 127-130

2. Bearn AG, Billings BH, Sherlock S (1951) Hepatic glucose output and hepatic insulin sensitivity in diabetes mellitus. Lancet 2: 698-701

3. Heller N, Kalant N, Hoffman MM (1958) The relationship be- 
tween insulin responsiveness and blood glucose half-life in normal and diabetic subjects. J Lab Clin Med 52: 394-401

4. Shen SW, Reaven GM, Farquhar JW (1970) Comparison of impedance to insulin mediated glucose uptake in normal and diabetic subjects. J Clin Invest 49:2151-2160

5. Harano Y, Ohgaku S, Hikado H, Haneda K, Kikkawa R, Shigeta Y, Abe H (1977) Glucose, insulin and somatostatin infusion for determination of insulin insensitivity. J Clin Endocrinol Metab 45: 1124-1127

6. Rabinowitz D (1970) Some endocrine and metabolic aspects of obesity. Ann Rev Med 21:241-253

7. Cheng J, Kalant N (1970) Effects of insulin and growth hormone on the flux rates of plasma glucose and plasma free fatty acids in man. J Clin Endocrinol 31: 647-653

8. Kalant N, Csorba TR, Heller N (1963) Effect of insulin on glucose production and utilization in diabetes. Metabolism 12: $1100-1111$

9. Kimmerling G, Javorski WC, Olefsky JM, Reaven GM (1976) Locating the site(s) of insulin resistance in patients with nonketotic diabetes mellitus. Diabetes 25: 673-678

10. Brown PM, Tompkins CV, Juul S, Sönksen PH (1978) Mechanism of action of insulin in diabetic patients: a dose-related effect on glucose production and utilization. $\mathrm{Br}$ Med $\mathrm{J}$ 1: $1239-1242$

11. Kalant N, Leibovici T, Rohan I, Ozaki S (1979) Interrelationships of glucose and insulin uptake by muscle of normal and diabetic man. Diabetologia 16:365-372

12. Kalant N, Leibovici T, Rohan I, McNeill K (1978) Effect of exercise on glucose and insulin utilization in the forearm. Metabolism 27: 333-340

13. Whitney RJ (1953) The measurement of volume changes in human limbs. J Physiol 121:1-27

14. Whitney RJ (1954) Circulatory changes in the forearm and hand of man with repeated exposure to heat. J Physiol 125: $1-24$

15. Trout DL, Estes EH Jr, Friedberg SJ (1960) Titration of free fatty acids of plasma: a study of current methods and a new modification. J Lipid Res 1: 199-202

16. Ozaki S, Kalant N (1977) A radioreceptor assay for serum insulin. J Lab Clin Med 90: 686-699

17. Kontos HA, Richardson DW, Patterson JL Jr (1966) Blood flow and metabolism of forearm muscle in man at rest and during sustained contraction. Am J Physiol 211: 869-876

18. Zelis R, Mason DT, Braunwald E (1969) Partition of blood flow to the cutaneous and muscular beds of the forearm at rest and during leg exercise in normal subjects and in patients with heart failure. Circ Res 24: 799-806

19. Kim J-O, Kohout FJ (1975) Multiple regression analysis: subprogram regression. In: Nie NH, Hull $\mathrm{CH}$, Jenkins JG, Steinbrenner K, Bent DH (eds) Statistical package for the social sciences, 2nd ed, McGraw-Hill, New York, pp 320-367

20. Zierler KL, Rabinowitz D (1964) Effect of very small concentrations of insulin on forearm metabolism. Persistence of its action on potassium and free fatty acids without its effect on glucose. J Clin Invest 43: 950-962

21. Olefsky JM (1976) Insulin's effect on glucose oxidation independent of glucose transport. Biochem Biophys Res Commun 71: 106-113

22. Andersen O, Gliemann J, Gammeltoft S (1977) Receptor binding and biological effect of insulin in human adipocytes. Diabetologia 13: 589-593

23. Thomas SHL, Wisher MH, Brandenburg D, Sonksen PH(1979) Insulin action on adipocytes. Evidence that the anti-lipolytic and lipogenic effects of insulin are mediated by the same receptor. Biochem J 184: 355-360

24. Ciaraldo TP, Kolterman OG, Siegel JA, Olefsky JM (1979) In- sulin-stimulated glucose transport in human adipocytes. Am J Physiol 236: E621-625

25. Bjorntorp P, Krotkiewski M, Larsson B, Somlo-Szücs Z (1970) Effects of feeding states on lipid radioactivity in liver, muscle and adipose tissue after injection of labeled glucose in the rat. Acta Physiol Scand 80: 29-38

26. Bjorntorp P, Berchtold P, Larsson B (1971) The glucose uptake of human adipose tissue in obesity. Eur J Clin Invest 1:480-485

27. Olefsky JM, Batchelder T, Colome S, Reaven GM (1974) Effect of intravenous glucose infusion on plasma insulin removal rate. Metabolism 23:543-548

28. Tranberg K-G, Thorell $J$ (1979) Variation in the disappearance of unlabeled insulin from plasma: Studies with portal and peripheral infusions. Diabetes 28:846-851

29. Tiran J, Avruch KI, Albisser AM (1979) A circulation and organs model for insulin dynamics. Am J Physiol 237: E331-339

30. Terris S, Steiner DF (1975) Binding and degradation of ${ }^{125}$ I-insulin by rat hepatocytes. J Biol Chem 250: 8389-8398

31. Gliemann J, Sonne O (1978) Binding and receptor-mediated degradation of insulin in adipocytes. J Biol Chem 253: 7857-7863

32. Goldstein S, Blecher M, Binder R, Perrino PV, Recant L (1975) Hormone receptors. 5. Binding of glucagon and insulin to human circulating mononuclear cells in diabetes mellitus. Endocrinol Res Commun 2:367-376

33. Olefsky JM, Reaven GM (1977) Insulin binding in diabetes. Diabetes 26:680-688

34. Helderman JH, Raskin P (1980) The T lymphocyte insulin receptor in diabetes and obesity: an intrinsic binding defect. Diabetes 29:551-557

35. DePirro R, Fusco A, Lauro R, Testa I, Ferreti F, DeMartinis C (1980) Erythrocyte insulin receptors in non-insulin-dependent diabetes mellitus. Diabetes 29:96-99

36. Neville DM Jr (1974) Receptors for polypeptide hormones: direct studies of insulin binding to purified liver plasma membranes. In Vitro 9:445-454

37. Chang KJ, Huang D, Cuatrecasas P (1975) The defect in insulin receptors in obese hyperglycemic mice: a probable accompaniment of more generalized alterations in the membrane glycoproteins. Biochem Biophys Res Commun 64: 566 573

38. Raizada MK, Tan G, Deo R, Fellows RE (1980) Cells cultured from the diabetic $(\mathrm{db} / \mathrm{db})$ mouse have a permanent decrease in insulin receptors. Endocrinology 107: 1652-1655

39. Olefsky JM, Reaven GM (1976) Effects of sulfonylurea therapy on insulin binding to mononuclear leukocytes of diabetic patients. Am J Med 60: 89-95

40. Prince MJ, Olefsky JM (1980) Direct in vitro effect of a sulfonylurea to increase human fibroblast insulin receptors. J Clin Invest 66: 608-611

41. Carpentier J-L, Gorden P, Freychet P, LeCam A, Orci L (1979) Relationship of binding to internalization of ${ }^{125}$ I-insulin in isolated rat hepatocytes. Diabetologia 17:379-384

42. Howard BV, Savage PJ, Nagulesparan M, Bennion LJ, Unger RH, Bennett PH (1979) Evidence for marked sensitivity to the antilipolytic action of insulin in obese maturity-onset diabetics. Metabolism 28: 744-750

Received: 8 April 1981

and in revised form: 9 November 1981

\section{N. Kalant}

Lady Davis Institute for Medical Research

Sir Mortimer B. Davis Jewish General Hospital

3755 Cote Sainte-Catherine Road

Montreal

Quebec, Canada H3T 1E2 